\title{
SUBJETIVAÇÕES RIZOMÁTICAS E A IDEIA DE CORPO SEM ÓRGÃOS EM A FÚRIA DO CORPO, DE JOÃO GILBERTO NOLL
}

\section{THE RHIZOME AND THE IDEA OF BODY WITHOUT ORGANS IN THE FURY OF THE BODY, BY JOÃO GILBERTO NOLL}

\author{
Francisca Gilmara da Silva ALMIRO ${ }^{1}$ \\ Roniê Rodrigues da SILVA ${ }^{2}$
}

\begin{abstract}
Resumo: O trabalho apresenta uma leitura da obra A Fúria do corpo, de João Gilberto Noll, a partir dos conceitos de Corpo sem Órgãos e Rizoma propostos pelos filósofos franceses Gilles Deleuze e Félix Guattari. Nesse sentido, objetiva estudar a construção identitária das personagens da referida narrativa, estabelecendo uma associação com essas noções filosóficas, problematizando, sobretudo, a errância das personagens e a linguagem utilizada para a composição da obra. Ao longo da leitura crítica, destacaremos como o texto de Noll nos desafia à construção de sentidos através de uma subjetividade constituída a partir de linhas de fuga, ideia discutida pelos filósofos supracitados. Ao adentrarmos no texto ficcional pelo viés de tais linhas, é possível entender como as personagens percebem e vivem suas experimentações rizomáticas. Desse modo, não se pretende aqui atribuir sentidos fechados à narrativa, mas sugerir que o Corpo sem Órgãos e o Rizoma são características que representam as experiências errantes das personagens encontradas na escrita de Noll.
\end{abstract}

Palavras-chave: Literatura Brasileira Contemporânea. João Gilberto Noll. Identidade. Corpo sem Órgãos. Rizoma.

\begin{abstract}
This paper presents a reading of The Fury of the Body, by João Gilberto Noll, based on the concepts of Body without Organs and Rhizome proposed by French philosophers Gilles Deleuze and Félix Guattari. It aims to study the characters' identity construction, establishing an association with these philosophical notions, exploring, especially, the characters' wandering nature and the language used in the composition of the work. Throughout this critical reading, emphasis will be given on the way Noll's text challenge us to construct directions through a subjectivity built from escape lines, a concept defined by Deleuze and Guattari. By reading the narrative through these lenses, it is possible to understand how the characters perceive and live their rhizomatic trials. Thus, the intention here is not to attribute closed meanings to the narrative, but to suggest that the Body without Organs and the Rhizome are features that represent the characters' wandering experiences in The Fury of the Body.
\end{abstract}

Keywords: Contemporary Brazilian Literature. João Gilberto Noll. Identity. Body without Organs. Rhizome.

\section{Introdução}

O autor João Gilberto Noll se destaca na literatura brasileira contemporânea, dentre outros aspectos, por problematizar, através das ações de seus personagens, questões como a da fluidez e da instabilidade identitária dos sujeitos, as quais emergem, de maneira contundente,

\footnotetext{
${ }^{1}$ Doutoranda pelo Programa de Pós-Graduação em Letras - Universidade do Estado do Rio Grande do Norte. Email: gilmaralgalmiro_21@hotmail.com

${ }^{2}$ Doutor em Literatura comparada. Professor Adjunto da Universidade do Estado do Rio Grande do Norte. E-mail: rodrigopinon2014@gmail.com
} 
como matéria de pauta no contexto de uma sociedade global. Numa perspectiva teórica pósestruturalista e em consonância com os Estudos Culturais, as correntes do pós-colonialismo e do pós-modernismo, essas são demandas estudadas, por exemplo, por autores como Stuart Hall e Zygmunt Bauman e que, ao longo deste artigo, serão consideradas numa relação com uma filosofia da diferença representada pelo pensamento de Gilles Deleuze e Félix Guattari. Nesse aspecto de inter-relação entre o texto literário e o filosófico, observaremos de que maneira a escrita literária de Noll problematiza a construção identitária de narradores e personagens nômades, os quais vivem em progressivos deslocamentos, tanto por espaços geográficos quanto por territorialidades psicológicas. De maneira específica, deter-nos-emos na apreciação crítica da obra A Fúria do corpo, na qual encontramos uma grande metáfora do homem que está imerso no desafio de entender sua(s) identidade(s) conflituosa(s).

Situado dentro do que, no cenário de produção literária brasileira, corresponde à pósmodernidade, o escritor João Gilberto Noll traz, em suas obras, personagens característicos do mundo contemporâneo, sujeitos que vivem em meio a divergências, a inquietudes subjetivas. Os textos do escritor representam, assim, homens e mulheres em conflitos consigo e com o outro, além de serem espaço de ficcionalização de uma errância na qual desejam viver. Em outras palavras, o autor transfere para a obra literária o que ele experiencia em determinada época com a subjetividade característica de sua escrita. Para isso, utiliza-se de um vocabulário simples, porém dinâmico, que se aproxima do leitor contemporâneo. Assim sendo, nos conduz ao conhecimento de narradores-personagens dotados de características que se assemelham ao sujeito da pós-modernidade. Sobre esse componente, Santiago (2010) destaca que "o narrador pós-moderno sabe que o 'real' e o 'autêntico' são construções da linguagem” (Santiago, 2010, p. 46-47). Dito de outro modo, o narrador entra em cena para usar, não a linguagem do autor, mas para ser aquele que está defronte aos leitores, no diálogo e no processo de construção da narrativa. É ele quem se utiliza da autenticidade da linguagem literária apresentada na obra.

Associando esse pensamento às obras do escritor gaúcho, ressaltamos que estas são caracterizadas pela crítica, além dos aspectos citados acima, pela mobilidade com que a narrativa se desenrola, bem como pela genialidade artística do escritor. Esta, por sua vez, nos permite entender a luta dos conflitos sociais, a fragilidade com que as relações humanas acontecem no decorrer dos textos e na idealização dos personagens.

Noll inicia sua trajetória literária com a publicação, em 1980, da obra $O$ cego e a dançarina, a qual permitiu a sua inserção entre os grandes nomes da literatura contemporânea brasileira. Desse modo, o escritor nascido em Porto Alegre (RS) nos evidencia as desventuras de uma sociedade marcada pelas desigualdades, pela fragmentação e pelos vazios de que se 
constituem os sujeitos humanos e sociais. Esta leitura é possível porque a literatura nos possibilita construir sentidos a partir da subjetividade com que cada autor trata a sua escrita literária. Cada artista utiliza-se de seu espaço social para construir não uma "reprodução", mas sim uma "representação", ficcional, daquilo sobre o que se reflete na realidade, dentro de condições possíveis.

Posterior à publicação de $O$ Cego e a dançarina, Noll publica A Fúria do corpo em 1981, objeto de estudo neste artigo, seguida de Bandoleiros em 1985, Rastros de verão em 1986, Hotel Atlântico em 1989, O Quinteto animal em 1991, Harmada em 1993. Esta última trata-se de obra pela qual o escritor recebeu o Prêmio Jabuti no ano seguinte. Sobre essa produção do autor gaúcho, a crítica observa que, desde os títulos que dão nome às obras, as características relevantes do que se constitui a narrativa do autor são: a errância, a transição dos personagens entre um espaço geográfico e outro, a constante busca do sujeito pelo encontro de si e do outro. Em Anjo das ondas, publicado em 2010, encontramos Gustavo, personagem que vive a transitoriedade entre Rio de Janeiro e Londres, cidades em que o garoto vive a travessia entre a infância e a vida adulta. No decorrer do romance, o personagem encontra-se em um processo de travessia, na busca pelo encontro consigo mesmo. Por esses poucos exemplos trazidos aqui, para rapidamente situar a escrita do autor, podemos afirmar que Noll utiliza-se de estratégias autorais, as quais nos demonstram que a produção literária contemporânea é constituída de estilhaços que caracterizam a noção de subjetividades, de busca de identidade, de trânsito, a partir de representações do meio social.

Ao relacionarmos esses aspectos presentes na obra aqui em estudo ao pensamento de Eagleton (2011), entendemos que:

As obras literárias não são misteriosamente inspiradas, nem explicáveis simplesmente em termos da psicologia dos autores. Elas são forma de percepção, formas específicas de se ver o mundo; e como tais, elas devem ter uma relação dominante de ver o mundo, a "mentalidade social" ou ideologia de uma época. (EAGLETON, 2011, p. 19)

O exposto por Eagleton (2011) incita a percepção de que a obra literária apresenta-se como uma caracterização da concepção de mundo do autor por meio dos seus personagens. Dito de outro modo, o autor literário, mais especificamente Noll, cria a obra e seus elementos compositores a partir da fisionomia intelectual que constitui a sua genialidade artística. É o que suscita o entendimento de que a literatura pode ser vista a partir de uma "representação" que o autor faz da realidade. Para Lukács (2011), "a fisionomia intelectual é o instrumento fundamental para definir uma personalidade em toda sua vivacidade" (LUKÁCS, 2011, p. 166). 
Dito de outro modo, o artista com suas estratégias, sejam do narrar, sejam do descrever, faz surgir personagens que se constituem de caracterizações relacionadas ao espaço social.

A produção literária de Noll, entendida em uma perspectiva pós-moderna traz o personagem que vive imerso, como dito anteriormente, na mobilidade, na valorização do movimentar-se, no sujeito envolto pela subjetivação capitalística, a qual não se reduz a modelos de identidade ou identificações, mas estabelece conexões sobre as diferentes formas de ver o mundo. Rolnik e Guattari (2011) nos destacam que estas não são formas errôneas, mas são outros modos de representar o mundo.

Sobre isso, Lukács (2011) nos aponta que:

É indispensável em toda grande arte, representar os personagens no conjunto de relações que os liga, por toda parte, com a realidade social e com a realidade e com seus grandes problemas. Quanto mais profundamente estas relações forem percebidas, quanto mais múltiplas forem as ligações evidenciadas, tão mais importante se tornará a obra de arte, pois ela se aproximará mais da beleza da vida [...]. (LUKÁCS, 2011, p.167).

Conectados a esse pensamento Guattari e Rolnik (2011) mencionam que há uma variedade nas máquinas de produção da subjetividade. Para os autores, esta produção acontece de diferentes formas, desde as mais tradicionais, nas quais temos o intermédio de máquinas territorializadas, ou seja, mais presas a sistemas de repressão social, bem como as menos tradicionais em que a produção acontece a partir de aspectos que rompem com estruturas socialmente entendidas como desvios de um sistema social, o que na filosofia de Deleuze e Guattari são associadas à ideia de Corpo sem Órgãos.

A narrativa aqui em estudo, A Fúria do corpo, é protagonizada por um casal de mendigos e destaca uma relação amorosa entre os personagens principais, os quais fogem dos padrões que a sociedade convenciona como correta. A partir da análise dessa relação, objetivamos estabelecer discussões para este trabalho, associando a identificação dos personagens às noções de Corpo Sem Órgãos e de Rizoma discutidas por Deleuze e Guattari no livro Mil Platôs. Essas discussões serão factíveis porque a obra escolhida para análise nos transporta a diversos caminhos, dentre eles o labirinto que faz da errância dos protagonistas, caracterizados como eternos viajantes, sujeitos indefinidos, constituídos de identidades fragmentadas, seres que estão à procura de lugares incertos. Noll nos aponta, em A Fúria do corpo, um labiríntico caminho em que os personagens se deixam influenciar pelo mundo à sua volta e esperam dele somente a possibilidade de continuar vagando, uma vez que eles não se sentem presos a nada, nem a ninguém. 


\section{A fúria do Corpo sem Órgãos}

Para iniciarmos a nossa discussão, tomemos as considerações de Deleuze e Guattari (1996) sobre a ideia de Corpo sem Órgãos - doravante $C s O$ - e de rizoma. Para os filósofos o $C s O$ : "Não é uma noção, um conceito, mas antes uma prática, um conjunto de práticas. Ao Corpo sem Órgãos, não se chega, não se pode chegar, nunca se acaba de chegar a ele, é um limite" (DELEUZE; GUATTARI, 1996, p. 9). Nessa mesma linha de pensamento filosófico, o conceito de rizoma pode ser associado à compreensão de que: “[...] Num livro, como em qualquer coisa, há linhas de segmentaridade, estratos, territorialidades, mas também linhas de fuga, movimentos de desterritorialização e desestratificação [...]” (DELEUZE E GUATTARI, 1995, p. 11). Dessa maneira, pensar rizomaticamente é, segundo os estudiosos supracitados, produzir também deslocamentos, (re)territorializações, (des)territorializações dentro de um processo em que são perceptíveis os devires, as linhas de fuga, as conexões com outras realidades.

Nesse raciocínio, o rizoma é tomado então como uma metáfora para se pensar formas de vidas distintas daquelas relacionadas a uma imagem da árvore/raiz e que seriam caracterizadas por um modelo de existência fixada, constituídas a partir dos preceitos institucionais. Numa relação com a figura do rizoma, as experiências de vida são pensadas, ao contrário, sob a ótica do devir em que as identidades se tornam desdobráveis, não fixadas, fluidas, com possibilidades de conexões diversas. Ao associarmos o pensamento dos filósofos à identificação dos personagens de obras como A Fúria do corpo, Rastros de verão, Harmada, entre outras, observaremos que a constituição dessa identificação ocorre por meio de um processo de desterritorialização e/ou reterritorialização, através das linhas de fuga, as quais seriam responsáveis por possibilitar ao sujeito a criação de agenciamentos com o fora, com uma exterioridade, fazendo-o escapar daquelas formas de experiência totalmente prontas. Nessa interpretação, os personagens de Noll nas obras citadas, mais especificamente em A Fúria do corpo, são apresentados ao leitor como seres fracionados em suas formações identitárias, assim como em suas relações sexuais. São sujeitos construídos a partir de deslocamentos, tanto geográficos, como psicológicos e socioculturais.

Dessa forma, na obra literária em estudo, a construção da identidade dos personagens se forma a partir da desestrutura, da desorganização de uma desautomatização do corpo, como defendida por Deleuze e Guattari na problematização de uma experiência relacionada ao CsO. Para que tal noção fique inteiramente clara, é preciso considerar que os autores supracitados discorrem a respeito dessa questão estabelecendo um contraponto com a compreensão do que 
seria um corpo como organismo. Para eles, esse corpo funcionaria a partir de três grandes estratos responsáveis por estabelecer uma ordem, um funcionamento padrão. O estrato do organismo teria a função de instituir uma forma hierarquizante, determinando funções e seria seguido pelos estratos da significância, pelo qual se atribuiria ao corpo um sentido e uma interpretação; e por último, o estrato da subjetivação fixaria o sujeito numa identidade prévia. A construção de um $C s O$ passa, então, necessariamente pela retirada desses estratos que serviriam para impedir o sujeito de se efetivar como potência: "O $\mathrm{CsO}$ é o que resta quando tudo foi retirado. E o que se retira é justamente o fantasma, o conjunto de significâncias e subjetivações.” (DELEUZE; GUATTARI, 1996, p. 12).

Os sentidos de rizoma e de $C s O$ em $A$ Fúria do corpo serão representados especialmente por um casal de mendigos que vive um relacionamento amoroso distanciado daquele que segue aos padrões estabelecidos convencionalmente pela sociedade. O distanciamento de padrões, aqui mencionado, ocorrerá sobretudo em decorrência de uma situação social desprestigiada, visto que eles aparecem em um contexto de miserabilidade. São seres que não têm casa, nem comida, não têm ambiente, nem identificação fixas. Eles deixam seus modos de vida, aparentemente estáveis, para fazer experiências em outros lugares sem retirar destes a mais vaga recordação para a(s) sua(s) construção(ões) identitária(s). Os personagens de A Fúria do corpo são apresentados na narrativa e entendidos por nós a partir do que Michel Maffesoli (2001) denomina por "sede do infinito" e do "desejo de outro lugar".

Nessa linha de pensamento destacamos que os personagens se distanciam de vivências que os prendem ao passado e fluem em suas andanças experimentando relações sexuais com homens, mulheres e adolescentes que encontram pelo caminho percorrido. Este fato, para as instituições como a igreja, o Estado e a família tradicional, é visto como desvio das normas estabelecidas por elas, uma vez que estar na posição de mendigo é ser tomado como um corpo que não tem utilidade dentro de uma sociedade capitalista, bem como manter relações com pessoas do mesmo sexo seria considerado uma espécie de transgressão.

Ainda que estes personagens possam ser tomados, por uma ótica capitalista, como corpos que não servem, justamente por não estarem preocupados com horários, mercadorias, rótulos, prazos, etc., na condição de $C s O$ são carregados de potência porque não se deixam fixar por uma rotina estratificada, preferindo investir num permanente processo de nomadização. Sobre essa condição de miserabilidade à luz da organização enquanto organismo, as instituições afirmam que há falta de potência nos corpos dos personagens mendigos, por eles constituíremse, devido a uma construção sociocultural, dos corpos que "nada são" e "nada podem". Contudo, a tese defendida por Deleuze e Guattari nos permite entender que os protagonistas 
que circulam na narrativa de Noll contrariam estas normas instituídas pelas relações de poder mencionadas por Foucault (1979) e que se direcionam à forma, organização e disciplina.

O que ora percebemos na narrativa de $A$ Fúria do corpo é que os personagens são apresentados inicialmente como pessoas miseráveis não somente na aparência, mas na própria metáfora do sujeito que desafia a (re)construção identitária, ora a partir de uma nova identificação através do nome, ora a partir de identidades conflituosas. O que vemos, portanto, representados na narrativa, são protagonistas que em suas andanças rompem com regras estabelecidas pelo meio social e continuam a andar em destino incerto, sem desejar dar um nome a si mesmo, sem identificar-se, sem assumir uma(s) identidade(s). Ambos os personagens confrontam a ideia de organização através da errância. Esta por sua vez, está relacionada na narrativa com a multiplicidade de vivências dos personagens que não cessam, nem se satisfazem, muito pelo contrário, acontecem em uma espécie de resposta ao que não se satisfaz mais.

Além destes aspectos, destacamos que qualquer identificação dada através de um nome próprio à personagem protagonista não aparece claramente definida no início da narrativa, fato que contribui para tomá-la como um sujeito não cerceado por uma significância. A mulher será batizada com uma cognominação apenas no desenvolvimento da trama, quando o personagem de nome João Evangelista a menciona como sua companheira. No trecho que segue percebemos o momento em que a nominação/identificação é dada ao personagem:

[...] um nome enfim, que não outorga um registro pessoal, um nome, um simples nome que adere aos que precisam de um nome, aos que perderam o seu, o nome do passado civil não, este lembra a mulher submersa ainda - mas ela também não gosta que se fale do passado, nisso nos confluímos, os dois, temos juntos um curso que começa aqui, nesse exato instante em que ponho a mão sobre a cabeça desta mulher e a consagro com o novo nome:

AFRODITE (Noll, 1981, p. 13)

Conforme se percebe no trecho supracitado, o personagem protagonista dá à sua companheira um nome que aparenta não ser aquele que aparece num registro oficial, legitimado pela instituição estatal, como se revelassem por essa feita o desejo de não se enquadrarem na condição de um corpo como imagem de um organismo. Afrodite, nome dado por João Evangelista a sua companheira de rua, não deseja lembrar do passado, da mulher que a constituía, de uma biografia, apontando, assim, para um (re)começo, uma nova vida, fato que, de certa maneira, traduz o rompimento com um modelo organizado e estabelecido institucionalmente, o que para Deleuze e Guattari projetaria a personagem para o universo de um CSO. Ademais, destacamos ainda que, pela leitura do trecho, o nome dado aos personagens 
não representaria nada mais além de uma nomenclatura comum, que pouco revelaria sobre a(s) identidade(s) da personagem, mas sim que fora dado apenas por regras institucionalizadas de que todos necessitam de um nome que os identifique no meio em que vivem. Desse modo, apontamos aqui para uma errância da cognominação, a qual se apresenta, através da personagem, de maneira provisória, como um devir.

A questão da cognominação dos personagens é importante de ser assinalada visto que, no início do romance, Noll nos apresenta de forma inominada dois personagens que assumem os papéis de protagonistas. Ambos, apesar da miséria em que se encontram, buscam o sentido da vida a partir da prática sexual, de momentos de desespero, de fúria do sexo, de relações que aparentemente não possibilitam nada mais que o prazer momentâneo. Recorrendo ao pensamento filosófico de Deleuze e Guattari, no que se refere a ideia de potência e de $\mathrm{CsO}$, entendemos que o casal de mendigos não se deixa reduzir a uma identificação estigmatizada pela sociedade em que estão inseridos. Contudo, representam os fragmentos de suas identidades em "desespero", na fúria do sexo, no prazer instantâneo e no desejo de ser errante.

Sobre a inominação vejamos o trecho que segue abaixo:

O meu nome não. Vivo nas ruas de um tempo onde dar o nome é fornecer suspeita. A
quem? Não me queira ingênuo: nome de ninguém não. Me chame como quiser, fui
consagrado João Evangelista, não que o meu nome seja João, absolutamente, não sei
quando nasci, nada, mas se quiser o meu nome, busque na lembrança o que de mais
instável lhe ocorrer. O meu nome de hoje poderá não me reconhecer amanhã. Não
soldo portanto à minha cara um nome preciso. João Evangelista diz que as naves do
Fim transportarão não identidades, mas o único corpo impregnado do um. (NOLL,
1981, p. 9)

O recorte supracitado nos aponta um narrador-personagem que apresenta uma identificação conflituosa. O sujeito é o ser que não tem nome e que não o deseja ter pelo fato de que seria comprometedor, para ele, assumir essa identificação, dando a si um nome e, consequentemente, assumindo uma identidade a partir da significância dele, quando o seu desejo é, na verdade, ser múltiplo, indefinido, errante. No trecho acima, observamos que o João Evangelista afirma que consagraram a ele este nome, mas que esta forma de identificação, feita pelo nome, não o reconhecerá em um futuro próximo, visto que, ao longo da trajetória errante poderão surgir outros, uma vez que o homem parece não desejar revelar algo sobre si através de sua cognominação.

Além disso, o desejo de uma não identificação do personagem através do nome nos permite pensar nessa figura como alguém que rompe com o que lhe foi imposto socialmente, pois em momento algum da narrativa o personagem importa-se com o que pensem a seu respeito. O que ora percebemos é que o narrador se apresenta como adepto a potencialidades 
de experimentações, um sujeito rizomático envolvido em possibilidades de ser um e ser outro (s). No trecho mencionado acima, o João Evangelista encontra-se em possibilidades de eterno devir, pois a identidade do personagem não está ancorada em um nome, muito menos em um arquétipo de sujeito homem instituído por uma sociedade patriarcal para a qual ele deveria se constituir por práticas que determinam um estado fixo. Ao contrário disso, ele se realiza por suas experiências inconstantes, em seu caminho de errante.

Outrossim, o personagem não apenas não fornece uma identidade através do nome, como também não sabe nada de seu nascimento. Ele deambula nas ruas, no espaço de peregrinação onde essa identificação nominal tem pouca ou nenhuma importância. O mesmo fato aparece mais uma vez no trecho:

[...] Nome não. Não adianta retalhar meus nervos, me inquerir, interrogar, nem mesmo torturar. Nome não. Quando criança me ensinaram assim: nome, idade, endereço, escola, cor preferida. Não, não vou entregar ao primeiro que aparece, nome, idade, essas coisas soterram um tesouro: sou todos, e quando menos se espera, ninguém. Meu nome não. Sou negro como aquele ali que bebe a pitu no balcão e esgravata com palito de fósforo a falta de dentes para rememorar a miséria. Não tenho cor. Sou incolor como uma posta e nada e morro agora neste instante se você vier... (NOLL, 1981, p. 24)

A ideia de pertencimento e de uma identidade fixada, como vemos, não são importantes para a personagem porque aparecem como aquilo que despotencializam o sujeito, impedindoo de entrar num universo de multiplicidades. O nome, a idade, o endereço e qualquer outra informação a respeito de seus gostos são criações institucionais, limitadoras, servindo para estratificar o indivíduo no eixo do organismo, da significância e da subjetivação. Ele prefere se formular de maneira rizomática, como um $C s O$, a partir de tudo aquilo que o cerca. Seria possível pensar a sua identificação a partir do que Bauman (2005) discute associado à metáfora da liquidez. O homem é, na visão de Bauman (2005), fruto do líquido mundo moderno, o qual passa por contínuas transformações. Nas palavras desse estudioso das identidades contemporâneas: "Com o mundo se movendo em alta velocidade e em constante aceleração, você não pode mais confiar na pretensa utilidade dessas estruturas de referência com base na sua suposta durabilidade (para não dizer atemporalidade)". (BAUMAN, 2005, p. 32-33).

Em outras palavras, tudo acontece a partir de movimentações que não cessam, uma vez que construímos nossas referências de modo a contemplar a velocidade e a mutabilidade das coisas, pois o que aparenta ser hoje poderá não ser nada amanhã. É o que parece acontecer com os protagonistas. Na citação literária acima percebemos que o narrador nos fala sobre sua infância, momento em que ele era condicionado a vivenciar determinadas regras, as quais, para 
ele, se fossem reveladas hoje, "soterram um grande tesouro" que poderia o fazer não acompanhar a velocidade exigida pela pós-modernidade e o deixaria estável em um ponto fixo.

Retomando as problematizações de Deleuze e Guattari (1996) destacamos que a experiência da mutabilidade das coisas acontece principalmente pela prática do Corpo sem Órgãos. Esta, por sua vez, acontece quando há um desmonte da integridade maquínica, o que, segundo os filósofos, seria uma experiência não prevista convencionalmente, mas possível de acontecimentos, pelo fato de que haveria a construção de agenciamentos, de ligações rizomáticas. No tocante ao nosso objeto de estudo, os personagens são acionados como essa integridade maquínica, desterritorializada, desmontada, pela qual vive experiências errantes. Em A Fúria do corpo, essa experimentação rizomática acontece a partir das relações sexuais vivenciadas entre os protagonistas, fato que desencadeia mais uma vez a percepção da ideia de personagens construídos como CsO. As relações sexuais, segundo Deleuze e Guattari (1996), constituem campo fértil para o desenvolvimento dessa prática de CsO. É nesse campo que são representados os corpos potencializados, os devires diversos, as formas de prazer que se revelam nas mais variadas situações. A obra em análise nos aponta personagens com experiências corporais/sexuais desterritorializadas e reterritorializadas, conforme representado:

[...] é só você pedir que serei todo amor, todos os deuses que você sonhou se encarnarão em mim e dentro de você serão mais deuses, mais deuses, não há limites para os deuses, eles serão cem, mil, milhões, e animarão teus passos, tua circulação, tua cabeça, tua chupada na minha pica e em todas as que ainda levantam e por que não as extintas, eles animarão a mesquinhez que te leva a esmo pelas calçadas mais imundas até que você devasse toda a podridão do mundo e ressurja iluminada para reinar: foi para isso que você foi feita, reinar-reinar, mesmo que quando chegar o reino você se veja no terminal da vida e o reino tenha duração de um suspiro, pois é para isso que você foi feita meu amor, enfio a mão na tua buceta sim, é como ela entra na tua xota apertadinha com todo o amor, ó. (NOLL, 1981, p. 21)

Em uma perspectiva rizomática o que percebemos no trecho acima é que os personagens fogem do que convencionalmente foi instituído como relação amorosa/sexual e passam a viver experiências marcadas por uma diferença. O sexo entre os protagonistas se apresenta como um elo de ligação entre eles e tanto o narrador-personagem quanto a sua companheira, nomeada por ele de Afrodite, experimentam novas relações com o corpo a partir de um fluxo de multiplicidades - cem, mil, milhões -, carregado de intensidades, as quais atuam no espaço corpóreo sem barreiras, sem censuras.

O que ora se configura é a relação de instabilidade discutida também por Michel Maffesoli (2001, p. 51): "É uma espécie de pulsão migratória' incitando [o indivíduo] a mudar de lugar, de hábito, de parceiros, e isso para realizar a diversidade de facetas de sua 
personalidade". Em outras palavras, as relações entre os personagens ocorrem numa perspectiva em que os corpos se abrem para os devires, para os diversos encontros que a vida lhes permite. O fato sugere a saída de uma visão una ou binarista das coisas, para adentrar em uma visão de rizoma, através da qual pode-se olhar para o múltiplo, para o campo da imanência do desejo que move a vida. Sobre isso vejamos um trecho da obra:

[...] Aqui a história se inicia e nada mais importa, um homem e uma mulher se reconhecem em plena Atlântica, não termos pouso nem casa não importa, aqui começa o esplendor de uma miséria, seguirmos é só isso: vem e não traz nada que possa desviar o alvo ainda imprevisível deste amor, despoja-te das relíquias viciosas do passado pelos teus próprios recursos, vem: você é ela e me acompanha prenhe da mais funda decisão, passos de guerreira pobre, renunciando ao repouso imediato, caminhando comigo como quem se conduz ao cativeiro de ouro, entrando pelas ruas de Copacabana como quem se dirige ao Reino, sei que essa mulher me trairá e eu a ela antes que o galo desperte, e cante, sei que essa mulher não perdoará nenhuma fraqueza em mim, sei que o nosso amor se plasmará com uma dor que nosso organismo ainda não conheceu, sei que nossos fracassos mais escandalosamente anônimos não conhecerão alento senão de suas graves feridas, sei que nossa separação doerá como o crime, sei que me perderei no seio dela, só o nosso amor incrustado nessa desolação fermentará a cada dia mais o seu encanto e nada nos faltará, nem mesmo este pão que reparto agora com ela e aqui metidos num beco imundo entre dois prédios [..] (NOLL, 1981, p. 10)

A representação da vida do personagem pode ser associada à do sujeito pós-moderno, o qual vive de maneira fragmentada e em incompletude constante. Como vemos, tanto o homem como a mulher são descritos como pessoas esfaceladas, desde a identificação nominal. Não são dadas a eles identificações convencionadas, mas são feitas referências quaisquer com a utilização de expressões como: essa mulher, esse homem, ainda que uma das personagens seja chamada de Afrodite - prostituta de rua que vive em condições de errância, assim como o companheiro. Este fato contribui para o levantamento dos perfis identitários de ambos.

É pertinente lembrar que o título do romance já alude a algo que foge aos padrões convencionais estabelecidos pelo meio social, um corpo que age pelo prazer da fúria momentânea. Ao pensarmos a respeito da acepção semântica da expressão "a fúria do corpo", somos levados à compreensão de que a palavra "fúria" remete a um sentimento que acontece subitamente, como um frenesi impetuoso. Problematizando-o a partir das concepções deleuzeguattarianas, relacionamos a uma espécie de intensidade, de afeto, que percorre o corpo enquanto imagem de um CsO.

\section{A linguagem rizomática de $A$ Fúria do corpo}

Sobre a constituição rizomática, Deleuze e Guattari (1995) afirmam que este conceito abrange a ideia de multiplicidade, de heterogeneidade, de conexão. Ao associarmos esse 
pensamento filosófico à leitura em tela, podemos dizer que o texto de Noll, enquanto criação estética, não apresenta entradas nem saídas hierárquicas, mas uma relação de conexão entre as partes, as quais constituirão as diversas formas de representação do conhecimento e do sentido na constituição do rizoma. Nas palavras dos filósofos:

Ser rizomorfo é produzir hastes e filamentos que parecem raízes, ou, melhor ainda,
que se conectam com elas penetrando no tronco, podendo fazê-las servir a novos e
estranhos usos. Estamos cansados da árvore. Não devemos mais acreditar em árvores,
em raízes ou radículas, já sofremos muito. Toda a cultura arborescente é fundada sobre
elas, da biologia à linguística. Ao contrário, nada é belo, nada é amoroso, nada é
político a não ser que sejam arbustos subterrâneos e as raízes aéreas, o adventício e o
rizoma (DELEUZE E GUATTARI, 1995, p. 10).

Nesse contexto, dizemos que o rizoma permite o acontecimento da desterritorialização, do desenrenraizamento e constitui-se como uma oposição aos sistemas de pensamentos dominantes a partir de uma lógica intensiva. No que se refere ao nosso objeto de estudo, podemos destacar que a organização textual, a construção identitária dos personagens e da própria significação acontecem de forma a se relacionarem com os processos rizomáticos que conduzem a própria formulação do enredo. Isso porque, ao observarmos a construção da narrativa, percebemos linhas de fuga nas subjetividades que constroem a linguagem literária, fato que nos permite estabelecer conexões com outros textos, como os agenciamentos com a narrativa bíblica, consoante se ler: “[...] Sei que essa mulher me trairá e eu a ela antes que o galo desperte, e cante [...]." (NOLL, 1981, p. 10). O trecho nos remete às passagens dos quatro evangelhos em que Jesus fora negado pelo apóstolo Pedro, como exemplificado em Mateus 26, 34, em que se diz que: "Jesus declarou: Em verdade te digo que esta noite, antes que o galo cante, me negarás três vezes! (BÍBLIA SAGRADA, 1991). Exemplos desse tipo de conexão entre o romance de Noll e outras narrativas nos permitem levantar a hipótese de que a organização textual de A Fúria do corpo acontece de forma a permitir agenciamentos, os quais nos possibilitam a construir sentido(s) que vão além daquilo que está linguisticamente marcado. É através dessas linhas de fuga, desses agenciamentos que percebemos a segmentaridade maleável do texto. Nessa perspectiva Deleuze e Guattari afirmam que: “[...] É seguindo uma relação meticulosa com os estratos que se consegue liberar as linhas de fuga, fazer passar e fugir os fluxos conjugados, desprender intensidades contínuas para um $C s O$. Conectar, conjugar, continuar [...].” (DELEUZE E GUATTARI, 1995, p. 27)

Não são raros os trechos em que podemos observar essas linhas de fuga, ainda que muitas vezes não apareçam marcadamente expressas no texto, mas nas entrelinhas. A exemplo, vejamos a passagem que segue: 
[...] Afrodite mais branca, diria que definha olhando as estrelas, a meia-lua, abre os braços em cruz e mostra as feridas na pele sobre as veias, gritam que é pico, que é preciso levá-la pro Miguel Couto porque é uma viciada em pico que está agonizando, que chegou muito heroína na cidade com leva de turistas, uma mulher gorda de braço com o marido fala que o Rio está infestado de todas as drogas que circulam na cara da polícia, que aquela viciada ali deve morrer pra servir de lição a todos os viciados da cidade, eu digo que não, que Afrodite jamais poluiu o organismo com drogas [...] (NOLL, 1981, p. 123).

O fragmento citado alude, mesmo que indiretamente, a uma passagem da vida de Jesus Cristo quando ele foi entregue a Pilatos para ser condenado a crucificação. Ademais, percebemos que, além da narrativa, da construção textual do enredo, as personagens se constroem como rizomas, a partir de processos de desterritorialização, de desenraizamentos que convergem para a transitoriedade, para a multiplicidade. O que ora percebemos é que os personagens se desterritorializam constantemente de seus espaços físicos e saem em busca de outros lugares para viverem por um período curto de tempo, como narrado abaixo:

[...] o meu trajeto cheio de recuos, paradas, síncopes, acelerações, andeios fora do ar, admito ser extravio às vezes, inexistente até, quem sabe existente mas já morto. Recorro às ruínas de um espelho que encontro pelo chão, ainda não sou ancião que presumo mereço, ainda não galguei por inteiro minha submissão ao Tempo, ainda não dobrei o suficiente meus joelhos em adoração ao mistério vivo, castiga-me este dia chuvoso que me prende à marquise sem a companhia dela que se extraviou como tantas vezes e tantas vezes reapareceu, dessa vez atrás de um poste, vejo o olhar de um adolescente intranquilo passar correndo de chuva, um raio se aproxima, desvia graças a deus a rota, me poupa, coço a chamada genitália com o vivo ardor de quem trabalha no afã mais fundo, me esmero em compor cá dentro alguma paisagem que substitua essa ruim daqui [...] (NOLL, 1981, p. 11)

Note-se a representação de um personagem instável que admite o prazer em ser errante, um sujeito que vive de desvios, entradas e saídas, com uma identidade que se assemelha a um rizoma, um ser que encontra o prazer em desterritorializar-se e reterritorializar-se seja no espaço físico, seja no psicológico. O que temos na representação identitária dos personagens da obra A Fúria do corpo são sujeitos que vivem em condições miseráveis, mas que sentem muito prazer pela forma como conduzem suas experiências. Em nossa leitura essa relação se estabelece com a noção de $C s O$, já que, ao explorar as potencialidades no processo de desterritorialização, o sujeito sai de sua condição de organismo e passa a criar novas possibilidades de (re) significação ou reterritorialização.

Entretanto, vale ressaltar que o sujeito, representado na obra em estudo, apesar de passar pelo processo de desterritorialização e reterritorialização não volta a um territorialização inicial. Vejamos o excerto que segue: 
[...] aqui a história se inicia e nada mais importa, um homem e uma mulher se reconhecem em plena Atlântica, não termos pouso nem casa não importa, aqui começa o esplendor de uma miséria, seguirmos é só isso: vem e não traz nada que possa desviar o alvo ainda imprevisível deste amor, despoja-te das relíquias viciosas do passado e vem pelos teus próprios recursos, vem: você é ela e me acompanha prenhe da mais funda decisão, passos de guerreira pobre, renunciando ao repouso imediato. [...] (NOLL, 1981, p. 10)

Consoante se nota, tanto o narrador-protagonista, como a sua companheira Afrodite, assumem identidades que se constroem e se reconstroem constantemente, mas não voltam a um ponto de origem, uma vez que estas são condicionadas à mutabilidade, ao constante devir. Assim, os personagens são seres errantes que buscam desorientar-se, desterritorializar-se através da própria errância. Eles acham-se e perdem-se em espaços sem fronteiras, móveis, que arrastam tudo e a todos em uma liquidez que não cessa e que impõe ao indivíduo a eternidade do movimento. É o que parece acontecer com os personagens de A Fúria do corpo.

\section{Conclusão}

Consoante se nota pelo que buscamos demonstrar, o sujeito representado por Noll em $A$ Fúria do corpo nega-se a voltar ao passado. Ele quer seguir sem destino sem buscar as experiências de um tempo passado, emergindo como um ser que cristaliza em suas memórias o trânsito fluido do momento presente. É o homem que se deixa levar pelas novidades que lhe aparecem na velocidade do movimento constante. Ele é um indivíduo que pode fazer suas escolhas em plena liberdade, que não leva em consideração as inferências feitas pelo outro.

$\mathrm{Na}$ territorialidade da rua na qual os personagens perambulam, homem e mulher adentram pelos becos e vielas e percebem um conjunto de possibilidades até então não vivenciadas. O simples fato de os personagens serem andarilhos já nos oferece a ideia de $C s O$. A eles é oferecido, além de outros aspectos, a experimentação, a posse momentânea do corpo um do outro. Eles mantêm relacionamentos sexuais que os fazem sentir-se revigorados por experimentarem situações novas. Nesse sentido, os andarilhos são reconhecidos por nós como pessoas que em um primeiro momento despertam curiosidade pelo estilo de vida que levam. Para eles era preciso sair do lugar cômodo em que se vivia e (re) construir-se, mesmo que a errância, o nomadismo e/ou a propícia busca de se encontrar por entre o que lhe é desconhecido seja a motivação para o devir, para a fluidez em uma sociedade que oferece apenas motivos para a fuga, para a transitoriedade.

Em suma, são personagens que representam a imagem da inquietação, da descontinuidade, do ir e vir sem destino algum. São indivíduos insatisfeitos com a monotonia 
da vida e que encontram no deslocamento do seu lugar comum o prazer momentâneo. São nômades que passam por processos de fragilidades, transitoriedades entre os espaços e acontecimentos da vida pelos quais vagam. Eles estão imersos em não lugares, desterritorializados, desapegados de suas raízes nacionais e identitárias.

\section{Referências}

BAUMAN, Z. Identidade. Entrevista a Benedetto Vecchi. Tradução brasileira de Carlos Alberto Medeiros. Rio de Janeiro: Jorge Zahar Editor, 2005.

BÍBLIA, Português. Bíblia Sagrada. Tradução de Ivo Storniolo e Euclides Martins Balancin. São Paulo: Paulus, 1991.

DELEUZE, Gilles \& GUATTARI, Félix. Mil Platôs: capitalismo e esquizofrenia, vol. 1. Tradução de Aurélio Guerra Neto e Célia Pinto Costa. São Paulo: Ed. 34, 1995.

EAGLETON, Terry. As ilusões do pós modernismo. Tradução de Elisabeth Barbosa. Rio de Janeiro: J. Zahar, 1998.

Marxismo e crítica literária. Tradução de Matheus Corrêa. São Paulo: Unesp, 2011.

FOUCAULT, Michel. Microfísica do poder. Organização e tradução de Roberto Machado. Rio de Janeiro: Edições Graal, 1979.

GUATTARI, Félix \& ROLNIK, Suely. Micropolítica: Cartografias do desejo. 11.ed. Petrópolis, RJ: Vozes, 2011.

LUKÁCS, Georg. A fisionomia intelectual dos personagens artísticos. In: e teoria da literatura. Rio de Janeiro: Civilização Brasileira, 1968.

. Marxismo

Arte e sociedade: escritos estéticos 1932 -967. Organização, apresentação e tradução

de Carlos Nelson Coutinho e José Paulo Netto. 2 ed. Rio de Janeiro: Editora, UFRJ, 2011.

MAFFESOLI, M. Sobre o nomadismo: vagabundagens pós-modernas. Rio de Janeiro / São Paulo: Record, 2001.

NOLL, João Gilberto. A Fúria do corpo. São Paulo: 1981.

SANTIAGO, Silviano. O narrador pós-moderno. In: . Nas malhas da letra. Rio de Janeiro: Rocco, 2010.

Recebido em: 10/02/2019

Aceito para publicação em: 16/04/2019 